\title{
The Development of Processing Taro Flour into Various Types of Dessert at Tompaso Baru Village, North Sulawei, Indonesia
}

\author{
Vidlina Lie Helena Vonny Opit Luckie Sojow \\ Magister Education Management Postgraduate Program \\ Manado State University, Indonesia
}

\begin{abstract}
Absract
This study aims to develop Talas bulbs into Dessets which are cultivated in the village of New Tompaso, by analyzing the value of nutrients from the products of cake Brownies and Pancakes which are based on Taro Flour. The research method used is research and development data in the process through analysis of Brownies and Pancake Products analyzed organoleptically and hedonic tests., data collected has been tabulated and analyzed using variance analysis formula (analysis of variance), nutritional content test results or parameters in Manado Baristand with Taro Flour Brownies results: carbonydrate 52.26\%, protein 5.15\%, water 12.74\%, ash content of $2.35 \%$, crude fiber of $3.41 \%$, fat of $27.50 \%$, gulkosa $1.15 \%$ and in Pancakes Carbonized taro flour $44.93 \%$, protein $4.93 \%$, water $24.52 \%$, ash content $1.59 \%$, fiber coarse $0.47 \%, 0.68 \%$ gulkosa and $24.03 \%$ fat, and the calculation states that the comparison to two dessert products between brownies and inclined pancakes that are preferred is pancakes with presentation results: aroma $92.22 \%$, texture $91.11 \%$, shape $86.67 \%$ and $90 \%$ taste.
\end{abstract}

Keywords: Taro flour, Dessert

DOI: $10.7176 / \mathrm{JEP} / 10-17-02$

Publication date:June $30^{\text {th }} 2019$

\section{Introduction}

The Food security is important as one of the national development priorities. Food is a basic need as well as being the essence of human life so that food becomes a human right. The ability of domestic food production from year to year is increasingly limited. In order for national food sufficiency to be fulfilled, the efforts that can be made are increasing productivity of food cultivation by utilizing technology and efforts to diversify food. According to Koswara (2010: 8-9) taro has the potential to be used as raw material for flour because it has a high starch content of around $70 \%-80 \%$ and also gluten-free taro. Researchers chose to substitute wheat flour for taro flour because taro flour itself does not contain gluten so it can be consumed by sufferers of Celiac Disease and children who experience autism where they cannot consume gluten which will cause intestinal allergies which cause damage to the intestines and disrupt concentration (without gluten).

Rahmat Rukmana (2009: 8) Found that taro plants are native to the tropics. The results of the Nikola Ivanovich Vavilov expedition, a Soviet botanist showed that the origin of taro plants is the plains of China and India. The types of taro are various, including taro bogor (colocasia esculenta), taro fields (colocasia gigantea hook.f) and taro belitung (xanthosoma sagitifolium). The government makes non-wheat rice programs and the development of basic local food (MP3L) aimed at developing local food sources of carbohydrates other than rice and flour specifically prepared to support the implementation of subsidized food programs for low-income families. The phenomenon of taro production According to BPS SULUT that taro growth data from 2013 was $86.77 \%$ up in 2014 around $93.06 \%$, and $201595.40 \%$ even though in 2016 it dropped to $94.24 \%$, based on these data it can be seen that the prospect taro yams in North Sulawesi can be said to be as abundant as South Minahasa Regency, especially Tompaso Baru Subdistrict, which was recorded by the Indonesian Agricultural Growth Study Center in 2014 with a production area of 7800 tons, while 2016 harvested 174ha with production of 10,000 tons (BPS Sulut 2016). Taro contains the value of nutrients, namely carbohydrates, proteins and fats, minerals and vitamins, so taro can replace the need for carbohydrates such as rice.

One of the taro-producing areas in the North Sulawesi area is South Minahasa. South Minahasa Regency has several sub-districts which are taro producers, namely Modoinding District, Tompaso Baru Subdistrict, and Motoling District, especially Tompaso Village. Newly, the average farmer as a taro tuber farmer grows abundantly in every segment of the road and garden and community home page. According to Siti Hamidah (2009: 33) dessert is a popular product, also a type of food favored by the people of Indonesia. Famous dessert products such as sweet bread, white bread, pastries / cookies, cake, and pastry products. Cake is a product that has a sweet taste, rich in fat and sugar. The basic cake dough contains flour, sugar, fat, eggs, milk, and the ingredients of the developer. To make cake needed precision as well as making bread. This is related to the accuracy in material weighing, and mixing techniques. Taro flour is suitable for making cakes because based on the results of the researchers taro flour can replace the function of $100 \%$ flour, which means it can replace wheat flour as a whole.

Processed cake products made from taro will be made into various processed cakes, namely Brownies and 
Pancakes. In addition to utilizing taro, which is still lacking in processing, it is hoped that taro can provide improved quality in products both in terms of nutritional value and increase sales value in the market. In terms of price, the price of taro flour is cheaper than wheat flour. Taro has a savory, fluffy, fragrant aroma, texture still fits the characteristics of a standard product, and can be accepted among the public, especially for those who have gluten allergies or those on a flour diet. Cake made using taro flour can also be presented with an attractive, good decoration and of course economic value.

\section{Literature review}

2.1. Benefits and uses of taro flour.

Pranowo (2004: 8) suggests that taro plants (Colocasia esculenta (L) Schott) are monocotyledonals native to the tropics. This plant originated from mainland India and China which was then brought to Russia by botanist Nikolai Ivanovich Vaviloc. Taro (Colocasia esculenta L, taro-taro or Araceae) is a type of tubers. Taro is thought to have been cultivated by humans since ancient times, even in the days before rice was planted by people. Now taro has spread to various parts of the world. Taro is a staple food, besides breadfruit, in several islands in Oceania. In Indonesia, popular taro is grown in almost all regions.

Achmad Subagio (2003: 8) states tubers called bonggol (tuber bulbs) that grow underground; height of 0.4$1.5 \mathrm{~m}$. Leaves 2-5 strands; with green stalks, dark green or purplish stripes, $23-150 \mathrm{~cm}$, the base is midrib shaped; leaf strands $6.60 \times 7.53 \mathrm{~cm}$, round eggs, jorong, or oval, with a tapered tip, sometimes purplish around sticking the stalk, the underside is waxy, the base is rounded. Inflorescence occurs in the cob in the armpit, stemmed from $15-60 \mathrm{~cm}$. The sheath of flowers is $10-30 \mathrm{~cm}$, consists of two parts, the upper one is longer, yellow orange and falls out. Butter is butter on the male part. Bunny fruit is green, bro. $0.5 \mathrm{~cm}$. Spindle-shaped seeds, longitudinal grooved (Mayasari N, 2010: 12). According to Mayasari N (2010: 12) in Lingga (1989: 50) taro tubers are located at the bottom of the main taro stem. These tubers are used as food ingredients. There are various types of taro, both wild and cultivated. There are even certain types that are planted as ornamental plants. The type of taro can be characterized by the color of the leaves and stems.

The phenomenon of taro production According to BPS North Sulawesi that taro growth data from 2013 was $86.77 \%$ up in 2014 around $93.06 \%$, and $201595.40 \%$ even though in 2016 it dropped to $94.24 \%$, based on these data it can be seen that the prospect taro yams in North Sulawesi can be said to be as abundant as South Minahasa Regency, especially Tompaso Baru Sub district, which was recorded by the Indonesian Agricultural Growth Study Center in 2014 with a production area of 7800 tons, while 2016 harvested 174ha with production of 10,000 tons (BPS Sulut 2016). Especially in Tompaso Baru Subdistrict production, according to the Government in Tompaso Baru Village production of taro tubers is about 5 tons every time, so almost every front and back of the house has taro trees which are then resold in the market, in Tompaso Baru 2 because taro is very easy to obtain then the residents there are only if they become substitutes for side dishes or even light snacks, the taro used is Talas Banten. chemical composition of several types of taro can be seen in the table below

Tabel 1. Chemical composition of several types of taro can be seen in the table below

\begin{tabular}{|l|c|c|c|c|}
\hline \multicolumn{1}{|c|}{ Karateristik (\%) } & Talas Bogor & Talas Banten & Talas Kalbar & Talas Malang \\
\hline Water Content & 77,00 & 84,65 & 67,08 & 53,50 \\
\hline Starch Content & 18,03 & 6,977 & 22,06 & 30,84 \\
\hline Protein ontent & 2,65 & 8,77 & 1,85 & 2,70 \\
\hline Fat level & 0,47 & 0,46 & 1,07 & 0,43 \\
\hline Ash Content & 7,84 & 8,53 & 5,37 & 1,95 \\
\hline
\end{tabular}

Source: BPTP Banten (2012)

Beneng taro tuber has a length of 1.2-1.5 m and weighs $35-40 \mathrm{~kg}$ at the age of 2 years. The tuber diameter reaches $45-55 \mathrm{~cm}$. Once the skin is peeled, the color of the yellow bulb appears. The tuber is produced from a tree as high as 2-2.5 m with giant leaves of 1 meter. It has a large bulb size but tastes not so good. Taro is a purple stem that often grows in the villages of Motoling and Modoinding. One of the taro-producing areas in the North Sulawesi area is South Minahasa. South Minahasa Regency has several sub-districts which are taro producers, namely Modoinding District, Tompaso Baru Subdistrict, and Motoling Sub-District especially Tompaso Village. Newly, on average farmers as taro tuber farmers, flourish on every road and garden segment and community home page.

Flour is a form of processing material by grinding or shoveling. In the grinding process the size of the material is minimized by means of crushed material that is pressed with the mechanical force of the grinder. Tapung is a product that has a low water content. Low water content plays an important role in maintaining the durability of a food ingredient. The amount of water contained in foodstuffs is influenced by several factors including the nature and type / origin of the material, the treatment that has been experienced by foodstuffs, storage air humidity, and the type of packaging. The most common way to reduce water content is by drying, either by drying or by drying.

According to Dahlia L (2014: 65) the process of making flour can be done in various ways depending on 
the type of tubers themselves. The process of making taro flour begins with washing and stripping fresh tubers, which are then sliced. Slice is intended to speed up the drying process. After that, soaking with water is done. Soaking is also a washing process because it indirectly has a cleansing effect. Then drying at a temperature of around $50-60{ }^{\circ} \mathrm{C}$ until the water content reaches $12 \%$. drying is carried out for 6 hours and usually the dried tubers are flipped back and forth to dry evenly. The results of drying are in the form of taro chips which are then ground to produce uniform taro flour which is sieved.

Wheat flour contains gluten which is not good for the human body, gluten itself in the human body is considered a poison because of that the author wants to make alternative flour that does not contain gluten and has many benefits for the body to substitute flour, namely taro flour. According to Yuliatmoko (2012: 3) Like other tubers, the most nutrients in taro are carbohydrates. The carbohydrate component in taro is a starch whose content reaches 77.9 percent. Amylopectin content which is high in taro is around $72-83 \%$, making the taste and texture of taro become sticky and fluffy like glutinous rice. Starch in taro has easy to digest properties, suitable to be used as baby food or a menu of post-illness healing. Besides protein, taro is also rich in essential vitamins and minerals. Like vitamin C, calcium, phosphorus and iron. Although not a nutrient, the fiber content in taro is also quite high. The presence of fiber is very good for maintaining the health of the digestive tract. In addition, the protein content in taro contains a variety of essential amnino acids but is low in histidine, lysine, isoleucine, tryptophan and methionine.

Budi Setyawan, (2015: 55-56) found that the superiority of the products possessed by taro flour is located in the nutritional content. As we know, taro tuber itself has very many benefits in the health sector, such as increasing the body's immune system, helping blood pressure to remain stable, healthy for the heart, overcoming fatigue, anti aging and many more. So it is not surprising if it is processed into taro flour, the properties it has are still high. Taro flour has higher carbohydrate, fiber, ash, fat, calories and vitamins than wheat flour. Taro flour is also easily mixed with other ingredients because it has a high water absorption capacity and fat absorption, and taro flour has a high fiber content, where the fiber content is enough to meet our fiber needs in a day. In addition, high-fiber foods are very good for digestion. Menkomsumsi taro flour is perfect for those who want to go on a diet. Comparison of Nutrition of Flour and Taro Flour can be seen in table 2.

Table 2. Comparison of Nutrition of Flour and Taro Flour

\begin{tabular}{|l|c|c|}
\hline \multicolumn{1}{|c|}{ Nutrition } & Flour & Taro Flour \\
\hline Water (\% bk) & 12 & 14.72 \\
\hline Carbohydrates (\% bk) & 77.3 & 75.80 \\
\hline Fat $(\%$ bk) & 1.3 & 1.05 \\
\hline Crude Fiber (\% bk) & 0.34 & 1.02 \\
\hline Protein $(\%$ bk) & 8.9 & 5.03 \\
\hline Energy (kcal) & 365 kkal per 100 gr & 377.55 kkal per 100 gr \\
\hline
\end{tabular}

Source. Tinambunan 2014

Taro tuber is very useful as an additional food ingredient and as a food buffer for the regions at the time of food scarcity (famine season), for example caused by long droughts and so on. Taro in several countries is also used as a staple food such as in Malaysia, Fiji, Samoa, Hawaii, Colombia, Brazil, the Philippines. In Hawaii, taro is served as a staple food called poi, which is taro made and mixed with water and then fermented before being eaten. Whereas in Brazil taro is made into bread. In the food diversification program, taro is also one of the nonrice carbohydrate-producing plants from tubers other than cassava and sweet potatoes which have an important role in diversifying food. (Kompasiana 2013: 9)

\subsection{Dessert}

Dessert began to vary by taking the basis of several dishes such as cake, pie, ice cream and so on combined with sauce, fruit, syrup, cream or a mixture of basic ingredients, thus creating a delicious and interesting dessert. The type of dish used as dessert can be served separately outside of the menu arrangement. As for friend tea dishes, as snacks, petit four, delivery, and so forth. According to Pascal M and Lin S J (2013: 54) Dessert is a dish that is served at the end of courses in a set menu that is used to eliminate the impression of the taste of the previous dish and close the round of serving food. Dessert dishes are often called The final course or The last course and taste sweet or called sweet Dessert (dessert) is a dish that is served after the main course (main course) as a dessert or commonly referred to as dessert. Dessert usually has a sweet and refreshing taste, sometimes some taste salty or a combination. The function of dessert in courses is as a refreshing dish after eating a main course which sometimes has a fishy aroma or taste and eliminates good taste. Initially a dessert dish that is served in the form of fresh fruits without processing.

According to Teguh K (2015: 34) dessert is food that is served at the end of the presentation. which is a standard part of Western food, is a relatively new development. Before the rise of ordinary class people in the 19 th century and the use of machinery in the candy industry, sweets were more a priority of aristocracy or holiday food which was very rare. When sugar becomes cheaper and more available, the development and 
popularity of dessert. The word dessert itself is a translator of the word dessert in English that comes from Old French desservir which means "to clean the table". The word dessert is often used in English-Hiberno, American English, Canadian English, Australian English and French.Wayne G (2013: 55) believes dessert is a dish that is served after the main course as a dessert or commonly referred to as dessert. Dessert usually has a sweet and refreshing taste, sometimes some taste salty or a combination. Candies, puddings and $\mathrm{ft}$ afters digunakan are more often used in various types of desserts from the British Commonwealth. According to Debrett, 'pudding' is a more appropriate term, 'dessert' or 'dessert' is only used when the food comes from fruits, and sweets are koloquial or informal terms.

This dessert is seen as a separate meal or snack rather than a meal, and can be eaten shortly after the main meal (usually in an informal setting). Some restaurants specialize in desserts. Some customs or cultures do not have separate sweet final dishes. However, they mix sweet and unique foods throughout the meal as in Chinese food. But sometimes, they leave dessert on certain events. The type of dish used as dessert can be served separately outside of the menu arrangement. As for friends drinking tea, as a snack, petit four, delivery, and so forth. The composition is $100-120$ grams.

The function of dessert in courses is as a refreshing dish after eating a main course which sometimes has a fishy aroma or taste and eliminates good taste. Initially a dessert dish that is served in the form of fresh fruits without processing. Along with the times, dessert began to vary by taking the basics of some dishes such as cake, pie, ice cream and so on combined with sauce, fruit, syrup, cream or a mixture of basic ingredients, thus creating a delicious dessert and interesting (Heartline Radio 2014: 7).

\section{Research Method}

The research used is research and development, this research method produces certain products and tests the effectiveness of these products.

1. Product Testing. According to Sofiah and Achyar (2008), based on the sensitivity level and the objectives of each test, there are several types of panels, namely expert panels, trained panels, and untrained panels. The data sources to be taken are 15 panelists (Sofiah and Achyar 2008: 34)

2. Data Collection TechniquesQuestionnaireQuestionnaires are a number of written questions made using the hedonic scale. Test methods are generally used to test the level of preference for a product or food ingredient, in a hedonic scale study using six hedonic scales (Sofiah and Achsyar 2008: 44).

3. Research IntrumentSample A (Taro Flour Brownies and Sample B (Taro Flour Pancake) as a comparison of product design planning. The recipe used to make various dessert (cake). Recipes and How to MakeIngredientsa) Material A:b) 8 btr egg yolksc) 100 gr of sugard) 1/2 tsp Sp (optional, I don't use it)e) Material B: siftedf) 75 gr of all purpose flourg) 25 grams of Maizenah) 4 egg whites, beat until soft peaki) $75 \mathrm{gr}$ butter / margarine, meltingHow to make :1. Beat the egg yolks and sugar until thick and thick, expand on foot2. Mix little by little Material B while sifting3. After that mix the egg whites that have been shaken gradually into the egg yolk mixture, stirring again until smooth4. Finally mix the melted butter into the mixture, mix well. Pour into a round pan $20 \mathrm{~cm}$ in diameter, bake with a temperature of 180 degrees Celsius until cooked.

4. Data AnalysisThe analysis technique used in this study was testing nutrients from both Dessert (Brownies and Pancakes) products

5. Recipe ValidationFor product validation carried out by experts or experts who are professionals in the field of Catering or food experts to assess the newly designed products, in this study the experts presented to assess the product are 2 experts who are experts in the culinary field at Maleosan Swissbel Hotel Manado Department Pastry and Bakery.

\section{Result and Discussion}

Dessert is a snack that is popular in the community and is often found in the market. This can be evidenced by the availability of cakes in almost all shops that sell snacks in shops and stalls in remote villages. This picture indicates that almost all levels of society are used to enjoying various desserts. Dessert is preferred because of its distinctive color, aroma, taste and texture. To reduce dependence on wheat flour, in making cakes using the basic ingredients of taro flour. Taro flour is relatively cheaper, easier to obtain and easier processing.

Taro flour has a soft and white texture resembling wheat flour so that it can be processed into various processed products in both wet and dry forms. The problem that arises in the manufacture of taro flour is how the comparison of the quality of taro flour cake is superior to wheat flour, how the level of people's preference for taro flour cake and the nutritional content contained in taro flour. To overcome this problem, it is necessary to experiment with making taro flour which is processed into various desserts (brownies and pancakes). For better results, an assessment is needed, namely subjective assessment and objective assessment. Subjective assessment includes sensory test and organoleptic test, while objective assessment is done by laboratory tests to determine nutrient content. 
Table 3 . Organoleptic Brownies Test Data

\begin{tabular}{|c|c|c|c|c|c|}
\hline No. & Responden & Tekstur & Taste & Smell & Form \\
\hline 1 & 1 & 3 & 3 & 4 & 1 \\
\hline 2 & 2 & 4 & 4 & 4 & 4 \\
\hline 3 & 3 & 1 & 4 & 6 & 4 \\
\hline 4 & 4 & 2 & 4 & 3 & 3 \\
\hline 5 & 5 & 6 & 3 & 4 & 5 \\
\hline 6 & 6 & 6 & 5 & 2 & 2 \\
\hline 7 & 7 & 2 & 5 & 6 & 2 \\
\hline 8 & 8 & 4 & 6 & 3 & 2 \\
\hline 9 & 9 & 2 & 2 & 6 & 5 \\
\hline 10 & 10 & 3 & 2 & 4 & 6 \\
\hline 11 & 11 & 3 & 3 & 4 & 3 \\
\hline 12 & 12 & 4 & 5 & 3 & 2 \\
\hline 13 & 13 & 3 & 3 & 5 & 3 \\
\hline 14 & 14 & 3 & 4 & 4 & 4 \\
\hline 15 & 15 & 2 & 3 & 2 & 4 \\
\hline & Total & $\mathbf{4 8}$ & $\mathbf{5 6}$ & $\mathbf{6 0}$ & $\mathbf{5 0}$ \\
\hline & Presentation & $\mathbf{5 3 . 3} \%$ & $\mathbf{6 2} \%$ & $\mathbf{6 6 . 6} \%$ & $\mathbf{5 5 . 5 \%}$ \\
\hline
\end{tabular}

Source. results of data processing, 2017

After the results of the organoleptic test data, it is known that the organoleptic test for taro-based cakes (brownies and pancakes) is known that in 2 samples there were 2 nutrition and food experts and 15 panelists, PKK and Communities in Tompaso Village It is only on average that the two products of cake brownies and pancakes made from taro flour can be consumed safely starting from the taste that is tasty and legit and the appropriate color and dense texture.

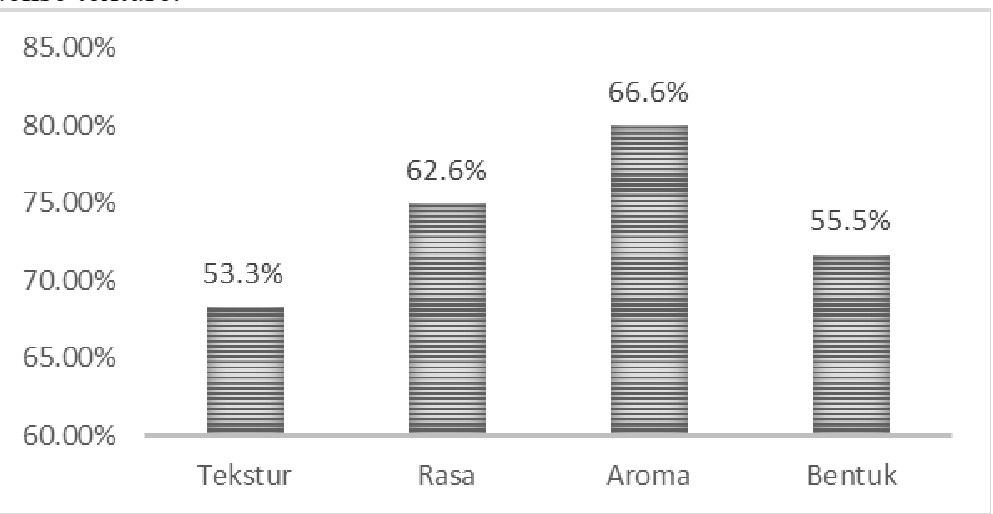

Picture 1. Diagram presentation dessert brownies from taro flour

The presentation diagram above shows that texture is at a value of $53.3 \%$ because of the 15 panelists who were given a sample of people stated 2 were very very like, 3 people said they really liked and 5 people liked and 5 liked, while the presentation of taste was $62.6 \%$ with 2 people states very very like, 8 people stated very like, 2 people expressed likes and 3 people stated rather like, while presentation on aroma $66.6 \%$ with 4 people stated very very like, 6 people stated very like, 4 likes and 1 person stated rather like, $55.5 \%$ of presentations from forms with 3 people said they were very very like, 7 people said they were very happy, and 5 people stated rather like it.

Table 4. Chemical, Physical and Microbiological Test Results of Taro Flour Pancakes

\begin{tabular}{|c|l|c|c|l|}
\hline No. & Parameter & Analisis Result & Unit & \multicolumn{1}{|c|}{ Model Analisis } \\
\hline 1 & Carbohydrate & 44.93 & $\%$ & Perhitungan \\
\hline 2 & Fat & 24.03 & $\%$ & SNI 01-2891:1992 Butir $8: 1$ \\
\hline 3 & Protein & 4.93 & $\%$ & SNI 01-2896:1992 Butir 5,5 \\
\hline 4 & Water & 24.52 & $\%$ & SNI 01-2896:1998 Butir 5.1 \\
\hline 5 & Ash & 1.59 & $\%$ & SNI 01-2896:1998 Butir 6.1 \\
\hline 6 & Coarse fiber & 0.47 & $\%$ & SNI 01-2896:1998 Butir 11 \\
\hline 7 & Glukose & 0.68 & $\%$ & SNI 01-2896:1998 Butir 3.1 \\
\hline
\end{tabular}

Source : Baristand Manado. NO 3055/Bd/BP.8/LB/XI/2017

Product testing for respondents in Tompaso Baru Subdistrict with 2 product samples was carried out on PKK mothers in the Tua Law office in New Tompaso Village 2 by distributing questionnaires and presenting 
products to PKK mothers as many as 15 people divided into 3 Villages taken from each - each village 5 respondents PKK mothers in the village to taste the results of various dessert products (Brownies and Pancakes) with a sample code A (Taro Flour Brownies) and one comparison sample with the sample code B (Taro Flour Pancake) with the intention to find out whether respondent prefer sample A or sample B then the research carried out gets the results as below with testing samples using hedonic tests and calculated the hedonic quality test using variance analysis

The researcher conducted a hedonic and organolepic test by comparing the two sample A and Pancake B brownies products, after testing the product by sharing the questionnaire and tasting the two samples which were preferred by PKK and Community mothers in Tompaso Baru Village was B sample Taro flour pancakes with a presentation of texture $91.11 \%$, taste $90 \%$, aroma $92.22 \%$, and form $86.67 \%$.From the results of chemical, physical and microbiological testing 6 the content of nutrients that are very useful for the human body, such as: Carbonhydrous $75.80 \%$, fat $1.05 \%$, protein $3.05 \%$, crude fiber $1.02 \%$, water $14.72 \%$ and ash $3.40 \%$ six parameters are units analysis of orange laboratory of the Industrial Research and Standardization Center (Baristand) Manado, the results of which have been issued on the 23rd of 0ckober 2017, Aroma is better and has a very consistent taste with a comparison of slightly less sweet and very sweet and long lasting Dessert (Brownies and Pankcake) taro flour) if stored in the refrigerator 1 week.

Based on the research that has been carried out, taro flour can be made as a cake or substitute for wheat flour, so by conducting this research encouraging respondents or in this case PKK mothers in Tompaso Baru village in developing local potential in their respective areas in the field agriculture is more specifically the use of Tuber Talas to be a valuable industry that can be developed locally and can be developed to the national and international level.

\section{Conclussion}

1. The conclusions of the research conducted by the researchers in making Aneka Dessert Brownies and Flour Talas Pancake, which were carried out in the first 2 stages, were the first phase of the trial conducted in Tompaso Baru II Village on 15 Community Respondents as the pilot stage to get one of the evaluation materials recipe, before entering stage 2, namely the use test, after the first phase of the test is completed with various considerations and revisions from both the recipe and presentation, the researcher carries out the phase 2 test which the sample making process is carried out at the Panelist's House so that the respondents can see the process directly manufacture.

2. Both samples were tested for nutrient content or parameters in Baristand Manado with the results of Taro Flour Brownies: carbonized 52.26\%, protein 5.15\%, water $12.74 \%$, ash content $2.35 \%$, crude fiber $3.41 \%$, $27.50 \%$ fat, $1.15 \%$ gulkosa and Pancake Carbonized Taro flour $44.93 \%$, protein $4.93 \%, 24.52 \%$ water, $1.59 \%$ ash content, $0.47 \%$ crude fiber, $0.68 \%$ gulkose and fat $24.03 \%$.

3. After testing the parameter nutritional content, the researcher continues the research by carrying out the use test using a sample assessment technique based on the hedonic test method, using a sample of brownies as the base material for comparison with the aim to be able to see the favorite differences between pancakes and comparison samples with analyzing the hedonic test results using the variance analysis formula with a significance level of 5\%, from the study after the data collected through questionnaires were distributed to PKK mothers in Tompaso district, the researcher obtained results namely between taste, aroma, texture and shape from samples of cake (taro flour brownies and pancakes) and samples there is a comparison that pancake products made from taro flour are preferred with results: aroma $92.22 \%$, texture $91.11 \%$, form $86.67 \%$ and taste $90 \%$ received in terms of good taste and legit as well as the appropriate color and texture soft.

4. The researcher conducted a hedonic and organolepic test by comparing the two sample A and Pancake B brownies, after testing the product by sharing the questionnaire and tasting the two samples that were preferred by PKK and Community members in New Tompaso Village were samples B is taro flour pancake with a presentation of texture $91.11 \%$, taste $90 \%$, aroma $92.22 \%$, and form $86.67 \%$. There is a difference between the two samples.

\section{References}

Achmad Subagio. 2003. Jurnal Teknologi dan Industri Pangan. Jurusan Teknologi Hasil Pertanian Fakultas Teknologi Pertanian Universitas Jember

Anggriawan R. 2010. Pengaruh Metode Penggilingan terhadap Sifat Fisik, Kimia, dan Fungsional Tepung Talas Hibrida [skripsi]. Bogor. Program Sarjana, Universitas Jendral Soedirman Purwokerto.

Anni Faridah. 2009. Patiseri. Jakarta: Direktorat Pembinaan Sekolah Menengah Kejuruan

Balai Pengkajian Teknologi Pertanian (BPTP) Banten, Reduction of oxalate levels in Banten local's taro through immersionin salt water Volume 1, Nomor 7, Oktober 2015 ISSN: 2407-8050 Hal: 1707-1710 syahrizal muttakin

Budi Setiawan. 2015. Peluang Usaha Budidaya. Pustaka Baru Press. Yogyakarta 
Desrosier, Norman W, 2008. The Technology of Food preservation, Third Edition (Teknologi Pengawetan Pangan, Edisi Ketiga). Penerjemah: Muchji Mulijohardjo. Jakarta: Penerbit Universitas Indonesia.

Di Akses dari Internet :

Faridah DN. 2011. Perubahan Karakteristik Kristalin Pati Garut (marantaarundinaceael.) dalam Pengembangan Pati Resisten Tipe III [disertasi]. Bogor. Program Sarjana, Institut Pertanian Bogor.

Food calory. (2016) Retrieved Febuary, from www.caloriking.com.au

Gisslen, Wayne.(2009). Professional Baking Fifth Edition. New Jersey: John Wiley \& Sons, inc., Hoboken, New Jersey.

Hardiman, Intanna (ed). 2011. Cake Non Terigu untuk Jualan. Gramedia Pustaka Utama. Jakarta.

Hartati NS danTitik KP. 2003. Analisis kadar pati dan serat kasar tepung beberapa kultivar talas (ColocasiaesculentaL. Schott). JurnalNatur Indonesia 6(1): 29-33

https://dianmahayanti.wordpress.com/f-b-product-2/dessert/pengertian-dessert/

Indrasti D. 2004. Pemanfaatan Tepung Talas Belitung (Xanthosomasagitifolium) dalam Pembuatan Cookies [skripsi]. Bogor. Program Sarjana, Institut Pertanian Bogor.

Kohmariah Kokom, Dkk. 2008. Job Sheet Pengolahan Makanan Kontinetal. Jurusan PPTB FT Univeristas Negeri Yogyakarta.

Kusnandar Feri, 011. Analisis pangan. PT.Dian Rakyat : Jakarta

Kusnandar F, Nuraida, dan Palupi. 2007. Pemanfaatan Talas, Garut, dan Sukun sebagai Prebiotikdan Formulasi Sinbiotik sebagai Suplemen Pangan. Bogor: Institut Pertanian Bogor.

Kewo, C. L., \& Afiah, N. N. (2017). Does Quality of Financial Statement Affected by Internal Control System and Internal Audit?. International Journal of Economics and Financial Issues, 7(2), 568-573.

Lies Dahlia. 2014. Hidup Sehat Tanpa Gluten. Elex media komputindo. Gramedia Press. Jakarta. 113hlm.

Mayasari N. 2010. Pengaruh Penambahan Larutan Asam dan Garam sebagai Upaya Reduksi Oksalat pada Tepung Talas (Colocasiaesculenta(L) Schott) [skripsi]. Bogor. Program Sarjana, Institut Pertanian Bogor.

Mayasari O. 2011. Pembuatan serbuk minuman jewawut (Pennisetumglaucum) instan dan uji penerimaan konsumennya [skripsi]. Bogor. Program Sarjana, Institut Pertanian Bogor.

Meyer LH. 2003. Food Chemistry. Textbook Publisher, New York.

Muttakin S. 2010. Beneng Primadona Banten

Nurcahyati E. 2010. Banten Kembangkan Talas Beneng sebagai Potensi PanganLokal

Parker R. 2003. Introduction to Food Science. United States of America: Delmar, Thomson Learning.

Pascal, M., and Lin Shin-Jie. 2013. The Aplication of Edible Polymeric Films adn Coatings in the Food Industry. Food Processing \& Technology. USA: Department of Food Science and Technology. The Ohio State University. Colombus. Ohio. USA

Pranowo D. 2004. Perencanaan Agroindustri Tepung Talas. Bogor. Institut Pertanian Bogor.

Rahman, Muhammad dan Amri Sofan. 2013. Strategi \& Desain Pengembangan Sistem Pembelajaran. Jakarta: Prestasi Pustakaraya

Rahmat Rukmana. 2009. Usaha Tani Umbi. Penerbit Kanisius. Jogjakarta

Rodríguez-García J., Puig A., Salvador A., Hernando I. (2013): Funcionality of several cake ingredients: A comprehensive approach. Czech J. Food Sci, Vol. 31, 2013, No. 4: 355-360

Samuel Putralo, Trias Septyoari Putranto, SST.Par., M.M 2014 uji organoleptik hasil jadi fettuccine menggunakan tepung talas, Jakarta

Siti Hamidah dan Sutriyati Purwati. 2009. Patiseri. Jurusan PTBB FT Universitas Negeri Yogyakarta.

Siti Hamidah. 2008. Job Sheet Patiseri I. Jurusan PTBB FT Universitas Negeri Yogyakarta.

Sofiah, B. D., Achyar, T. S. (2008). Buku Ajar Kuliah Penilaian Indra. (Cetakan ke-1). Jatinangor: Universitas Padjadjaran.

Sugiyono, 2008. Metode Penelitian Kunatitatif Kualitatif dan R\&D. Bandung Alfabeta.

Teknologi dan Kejuruan, vol. 40, no. 1, februari 2017: 87-97 Roma Idatul Koir, Mazarina Devi dan Wiwik Wahyuni Jurusan Teknologi Industri Universitas Negeri Malang. Alamat Kampus: Jl. Semarang No. 5 Malang 65145.87 analisis proksimat dan uji organoleptik getuk lindri substitusi umbi gembili (Dioscorea esculenta $L$ )

Wheat Associates us, 1983. Pedoman Pembuatan Roti dan Kue. Jakarta, Penerbit DJamatan.

Yuliatmoko, Petumbuhan Talas BantenSains dan Teknologi, Volume 13 Nomor 2, September 2012, 94-106 